\section{Regards sur l'économie allemande}

Bulletin économique du CIRAC

$97 \mid 2010$

Varia

\title{
Redevance audiovisuelle : nouveau régime en 2013
}

Isabelle Bourgeois

\section{OpenEdition}

Journals

Édition électronique

URL : http://journals.openedition.org/rea/4150

DOI : $10.4000 /$ rea.4150

ISBN : 978-2-8218-0890-4

ISSN : 1965-0787

Éditeur

CIRAC

Édition imprimée

Date de publication : 1 juillet 2010

Pagination : 34

ISSN : 1156-8992

Référence électronique

Isabelle Bourgeois, «Redevance audiovisuelle : nouveau régime en 2013 », Regards sur l'économie allemande [En ligne], 97 | juillet 2010, mis en ligne le 13 juillet 2010, consulté le 15 septembre 2020. URL : http://journals.openedition.org/rea/4150

Ce document a été généré automatiquement le 15 septembre 2020

(C) CIRAC 


\title{
Redevance audiovisuelle : nouveau régime en 2013
}

\author{
Isabelle Bourgeois
}

1 Les ministres-présidents des Länder, souverains en matière d'audiovisuel, se sont mis d'accord le 9 juin pour réformer en profondeur le régime de la redevance : elle ne sera plus perçue sur chaque récepteur radio et/ou TV détenu, mais sera prélevée par foyer, comme en France, quel que soit le nombre de récepteurs. Son montant ne dépassera pas le seuil actuel de 17,98 € par mois pour un téléviseur $+5,76 €$ pour une radio. Les nouvelles dispositions entreront en vigueur à l'expiration du Contrat d'Etat sur la redevance 2009/12. D'ici là, les Länder doivent élaborer un mode de calcul et une définition précise de l'assiette de la redevance.

2 Cette réforme tente de trancher un profond dilemme. En droit allemand, la redevance n'est pas une taxe, mais une sorte de cotisation due par la collectivité pour un service d'intérêt général dont la réalisation est confiée par les citoyens aux opérateurs de radiodiffusion publics. Or malgré le rang constitutionnel de ce système, la redevance s'assimile à un prélèvement obligatoire - et pour la Commission européenne, à une aide d'Etat (voir REA 86/08). En 2005, elle avait engagé contre la RFA une procédure, close en 2009 après que les Länder s'étaient engagés à réformer les points litigieux.

3 La solution trouvée par le fiscaliste et ancien juge de Karlsruhe, Paul Kirchhof, présente le grand avantage d'enterrer notamment le débat sur un prélèvement frappant les ordinateurs, et de réduire le coût lié à l'identification des fraudeurs. Reste à savoir le sort qui sera réservé à la GEZ, la centrale de perception de la redevance indépendante des pouvoirs publics car dépendant des opérateurs publics. Les débats promettent d'être houleux avant la construction définitive du nouveau régime... 
INDEX

Mots-clés : audiovisuel, média, redevance audiovisuelle, financement, politique des médias, télévision, chaîne publique, budget, réforme 